\title{
Analisis Ketersediaan dan Kebutuhan Air Berdasarkan Neraca Air di Sub DAS Cikeruh Jawa Barat
}

\section{(Analysis of Water Availability and Water Demand Based on Water Balance in Cikeruh Sub-Watershed West Java)}

\author{
Charina Agnesia*), Edy Suryadi, Sophia Dwiratna Nur Perwitasari \\ Program Studi Teknik Pertanian, Fakultas Teknologi Industri Pertanian Universitas Padjadjaran \\ *) email: charina17001@ mail.unpad.ac.id
}

\begin{abstract}
The increasing of the population along with changes in land use in the Cikeruh sub-watershed will affect the availability and the demand water as well as the level of water fulfillment in crucial sectors, namely: domestic, non-domestic, agriculture, industry, animal husbandry, and fisheries. This study aims to find out the most recent data on water availability and demand to determine the condition of the water balance in the Cikeruh sub-watershed. The method used in this research is descriptive analysis. Water availability was analyzed using the mock method and water availability was analyzed using SNI 6728.1-2015, Circular Letter of the Ministry of Public Works and Public Housing Number 07 of 2018, and related previous studies. The results showed that the total water availability in the Cikeruh sub-watershed was 207.552.347,99 $\mathrm{m}^{3} /$ year with an average water availability of $17.293 .529,00 \mathrm{~m}^{3} /$ month and a total water demand of $462.306 .728,53 \mathrm{~m}^{3} /$ year with an average water requirement of $38.525 .560,71 \mathrm{~m}^{3} /$ month. The Cikeruh sub-watershed experiences a water shortage (deficit) throughout the year. The highest water deficit occurred in May, that $-31.494 .255,51$ $\mathrm{m}^{3} / \mathrm{month}$ and the lowest deficit occurred in February, that $-3.210 .084,37 \mathrm{~m}^{3} / \mathrm{month}$. The water availability in the Cikeruh sub-watershed only can fulfill the water needs of the domestic, nondomestic, animal husbandry, and fishery sectors. The water availability in the Cikeruh sub-watershed has not been able to fulfill the water needs of the agricultural and industrial sectors.
\end{abstract}

Keywords: Deficit, Mock, Water Fulfillment Rate.

\begin{abstract}
ABSTRAK
Peningkatan jumlah penduduk disertai perubahan penggunaan lahan di Sub DAS Cikeruh akan mempegaruhi ketersediaan dan kebutuhan air serta tingkat pemenuhan air sektor krusial, yaitu: domestik, non-domestik, pertanian, industri, peternakan, dan perikanan. Penelitian ini bertujuan untuk memperoleh data terbaru ketersediaan dan kebutuhan air serta mengetahui kondisi neraca air di Sub DAS Cikeruh. Metode yang digunakan dalam penelitian ini adalah analisis deskriptif. Ketersediaan air dianalisis menggunakan metode mock dan ketersediaan air dianalisis menggunakan SNI 6728.1-2015, Surat Edaran Menteri PUPR (SE PUPR) Nomor 07 Tahun 2018, dan penelitian sebelumnya yang terkait. Hasil penelitian menunjukan total ketersediaan air di Sub DAS Cikeruh adalah 207.552.347,99 $\mathrm{m}^{3} /$ tahun dengan ketersediaan air bulanan rata-rata $17.293 .529,00 \mathrm{~m}^{3} / \mathrm{bulan}$ dan total kebutuhan air 462.306.728,53 $\mathrm{m}^{3} /$ tahun dengan kebutuhan air bulanan rata-rata 38.525.560,71 $\mathrm{m}^{3} /$ bulan. Sub DAS Cikeruh mengalami kekurangan air (defisit) sepanjang tahun. Defisit air tertinggi terjadi pada bulan Mei yaitu $-31.494 .255,51 \mathrm{~m}^{3} / \mathrm{bulan}$ dan defisit terendah terjadi pada bulan Februari yaitu $-3.210 .084,37 \mathrm{~m}^{3} /$ bulan. Ketersediaan air di Sub DAS Cikeruh hanya mampu memenuhi kebutuhan air sektor domestik, non domestik, peternakan, dan perikanan. Ketersediaan air di Sub DAS Cikeruh belum mampu mencukupi kebutuhan air sektor pertanian dan industri.
\end{abstract}

Kata Kunci: Defisit, Mock, Tingkat pemenuhan air. 


\section{PENDAHULUAN}

Fakta menunjukan bahwa jumlah penduduk meningkat setiap tahun. Peningkatan jumlah penduduk berimplikasi terhadap meningkatnya jumlah kebutuhan manusia. Air merupakan kebutuhan dasar setiap manusia. Jumlah penduduk yang meningkat berimbas pada meningkatnya jumlah kebutuhan air.

Sub DAS Cikeruh secara administratif terletak di wilayah Kabupaten Bandung, Kota Bandung, dan Kabupaten Sumedang. Laju pertumbuhan penduduk wilayah Sub DAS Cikeruh tahun 2010-2018 adalah sebesar 1,85\% untuk Kabupaten Bandung, 0,47\% untuk Kota Bandung dan 0,54\% untuk Kabupaten Sumedang (Badan Pusat Statistik Provinsi Jawa Barat, 2020). Beberapa Kecamatan di Sub DAS Cikeruh merupakan pusat-pusat perekonomian yang terus mengalami perkembangan yang akan berimplikasi semakin beratnya tekanan terhadap penggunaan lahan di Sub DAS Cikeruh (Amaru et al., 2013)

Terjadi perkembangan yang pesat baik dari segi aktivitas sosial maupun ekonomi di wilayah Sub DAS Cikeruh. Keberadaan pembangunan infrastruktur, kawasan pendidikan tinggi (KPT), serta tingginya aktivitas perekonomian menyebabkan tingginya minat penduduk untuk datang. Perkembangan sosial dan ekonomi di Sub DAS Cikeruh sejalan dengan perubahan penggunaan lahan. Selang waktu 1983 - 2002, terjadi penurunan luas lahan sawah sebesar 20,51\%, lahan hutan $9,75 \%$, semak rumput $2,79 \%$ dan tegalan $1,21 \%$ (Haryanto et al., 2007). Peningkatan jumlah penduduk dan perubahan penggunaan lahan di Sub DAS Cikeruh dapat mempengaruhi ketersediaan dan kebutuhan air daerah tersebut.

Berdasarkan hasil penelitian pada tahun 2011, kondisi neraca air di Sub DAS Cikeruh adalah defisit. Kondisi neraca air defisit menunjukan bahwa kebutuhan air Sub DAS Cikeruh belum sepenuhnya tercukupi. Ketersediaan air di Sub DAS Cikeruh hanya mampu memenuhi sektor domestik, peternakan dan industri (Zarkasih et al., 2018).

Ketersediaan air di suatu wilayah dapat saja berubah akibat adanya peningkatan jumlah penduduk serta alih fungsi lahan. Berdasarkan permasalahan tersebut, perhitungan ketersediaan dan kebutuhan air menjadi penting di Sub DAS Cikeruh untuk mengetahui potensi sumber daya air terkait dengan meningkatnya perubahan penggunaan lahan dan peningkatan jumlah penduduk. Kondisi neraca air dapat digunakan sebagai dasar untuk melakukan studi literatur mengenai rekomendasi upaya konservasi ketersediaan air yang dapat dilakukan di Sub DAS Cikeruh agar air tetap tersedia dengan jumlah yang memadai di masa yang akan datang.

\section{Tujuan penelitian}

Tujuan penelitian ini adalah untuk memperoleh data terbaru mengenai ketersediaan dan kebutuhan air serta untuk mengetahui kondisi neraca air di Sub DAS Cikeruh.

\section{METODOLOGI PENELITIAN}

\begin{abstract}
Alat
Alat yang digunakan pada penelitian ini adalah alat tulis, handphone, laptop, perangkat lunak microsoft excel, microsoft word, ArcGis 10.3, dan cropwat. Semua alat dalam penelitian digunakan untuk melakukan pengolahan data.
\end{abstract}

\section{Bahan}

Bahan yang digunakan pada penelitian ini adalah data iklim, data statistik, dan peta digital. Data iklim terdiri dari data curah hujan, data temperatur maksimum dan minimum, data lama penyinaran matahari, data kecepatan angin, dan data kelembaban tahun 2011-2020 dari Stasiun SPMK Pedca Universitas Padjadjaran, Stasiun Hujan Rancaekek, dan Stasiun Hujan Tanjungsari. Data statistik kawasan Sub DAS Cikeruh tahun 2020 meliputi data industri, kependudukan, peternakan, dan perikanan dari Kecamatan dan Badan Pusat Statistik. Peta digital yang digunakan pada penelitian ini adalah peta batas Sub DAS Cikeruh skala 1:25.000 dari BPDAS Citarum-Ciliwung, peta jenis tanah skala 1:100.000 dari BBSDLP, peta kemiringan lereng skala 1:19.000 dari DEMNAS, dan peta penggunaan lahan skala 1:25.000 dari Rupa Bumi Indonesia yang diperbaharui dengan Google Earth. 
Prosedur Penelitian

Perhitungan Ketersediaan Air Sub DAS Cikeruh Berdasarkan Metode Mock

1. Perhitungan evapotranspirasi potensial (Ep)

Evapotranspirasi potensial dihitung dengan metode Penman-Monteith menggunakan cropwat 8.0.

2. Perhitungan evapotranspirasi aktual (Ea) Evapotranspirasi aktual dihitung menggunakan formulasi berikut:

$$
\begin{gathered}
\Delta \mathrm{E}=\left(\frac{\mathrm{m}}{20}\right) \times(18-\mathrm{n}) \times \mathrm{Ep} \\
\mathrm{Ea}=\mathrm{Ep}-\Delta \mathrm{E}
\end{gathered}
$$

keterangan:

$$
\begin{array}{rlr}
\mathrm{Ea}= & \text { Evapotranspirasi Aktual (mm/bulan) } \\
\Delta \mathrm{E}= & \begin{array}{l}
\text { Selisih evapotranspirasi } \\
\text { dan }
\end{array} & \text { potensial } \\
& (\mathrm{mm} / \text { bulan }) & \text { aktual } \\
\mathrm{Ep}= & \begin{array}{l}
\text { Evapotranspirasi } \\
\text { (mm/bulan) }
\end{array} & \text { potensial } \\
\mathrm{m}= & \text { Exposed } \text { surface }(\mathrm{m}) & \\
\mathrm{n}= & \text { Jumlah hari hujan }
\end{array}
$$

\section{Perhitungan Water Surplus (WS)}

Water surplus dihitung dengan persamaan:

$$
\mathrm{WS}=(\mathrm{P}-\mathrm{Ea})+\mathrm{SS}
$$

Keterangan:

$$
\begin{aligned}
\mathrm{Ea}= & \text { Evapotranspirasi Aktual }(\mathrm{mm} / \text { bulan }) \\
\mathrm{P}= & \text { Curah Hujan (mm/ bulan) } \\
\mathrm{SS}= & \text { Tampungan Tanah (Soil Storage }) \\
& (\mathrm{mm} / \text { bulan }) \\
= & 0 \text { jika P-EA }>0 \\
= & \text { P-Ea jika P-EA }<0 \\
\mathrm{WS}= & \text { Water Surplus }(\mathrm{mm} / \text { bulan })
\end{aligned}
$$

4. Perhitungan Base Flow (BF), Direct Runoff (DRO), dan Storm Runoff (SRO)

Infiltrasi berdasarkan metode mock dapat dihitung dengan persamaan:

keterangan:

$$
\mathrm{i}=\mathrm{WS} \mathrm{x} \text { if }
$$

$\mathrm{i}=$ Infiltrasi $(\mathrm{mm} /$ bulan $)$

$\mathrm{WS}=$ Water surplus $(\mathrm{mm} /$ bulan $)$

if $=$ Koefisien infiltrasi (if)

Groundwater storage dihitung dengan persamaan:

$$
\mathrm{GS}=\{0,5 \times(1+\mathrm{K}) \times \mathrm{i}\}+\{\mathrm{K} \times \mathrm{GSom}\}
$$

keterangan:

$\mathrm{GS}=$ Groundwater storage $(\mathrm{mm} / \mathrm{bulan})$

$\mathrm{K}=$ Konstanta resesi aliran i $\quad=$ infiltrasi $(\mathrm{mm} / \mathrm{bln})$

GSom $=$ Groundwater storage bulan sebelumnya

Base flow dihitung dengan persamaan:

$$
\mathrm{BF}=\mathrm{i}-\Delta \mathrm{GS}
$$

keterangan:

$\mathrm{BF}=$ Base flow $(\mathrm{mm} /$ bulan $)$

$\mathrm{i}=$ Infiltrasi $(\mathrm{mm} /$ bulan$)$

$\Delta \mathrm{GS}=$ Perubahan groundwater storage

Direct runoff dihitung dengan persamaan:

$$
\mathrm{DRO}=\mathrm{WS}-\mathrm{i}
$$

keterangan:

DRO $=$ Direct runoff $(\mathrm{mm} /$ bulan $)$

$\mathrm{i} \quad=$ Infiltrasi $(\mathrm{mm} /$ bulan $)$

$\mathrm{WS}=$ Water surplus $(\mathrm{mm} /$ bulan$)$

Storm runoff merupakan air yang melimpas ke sungai ketika terjadi hujan deras, dihitung dengan ketentuan sebagai berikut:

- Jika presipitasi $(\mathrm{P})<\mathrm{SMC}$, maka nilai storm runoff $=0$

- Jika presipitasi $(\mathrm{P})>\mathrm{SMC}$, maka nilai storm runoff $=\mathrm{P} \times \mathrm{PF}$

\section{Perhitungan Total Runoff (TRO)}

$$
\mathrm{TRO}=\mathrm{BF}+\mathrm{DRO}+\mathrm{SRO}
$$

keterangan:

TRO = Total Runoff $(\mathrm{mm} /$ bulan $)$

$\mathrm{BF}=$ Base Flow (mm/ bulan)

$\mathrm{DRO}=$ Direct Runoff (mm/ bulan)

$\mathrm{SRO}=$ Storm Runoff $(\mathrm{mm} /$ bulan $)$

\section{Perhitungan Debit}

Perhitungan debit dilakukan dengan persamaan berikut:

$$
\mathrm{Q}=\mathrm{TRO} \times \mathrm{CA}
$$

keterangan:

$\mathrm{Q}=\operatorname{Debit}\left(\mathrm{m}^{3} /\right.$ detik)

TRO = Total Runoff (mm/ bulan)

$\mathrm{CA}=$ Catchment Area $\left(\mathrm{Km}^{2}\right)$

\section{Perhitungan Kebutuhan Air Sub DAS} Cikeruh

\section{Kebutuhan Air Domestik}

Kebutuhan air domestik adalah jumlah air yang diperuntukan untuk kegiatan rumah tangga, dihitung dengan persamaan:

$\mathrm{QDM}_{\mathrm{DM}}=$ Jumlah hari dalam 1 tahun $\mathrm{x}\left\{\frac{\mathrm{q}}{1000} \times \mathrm{P}\right\}$

Keterangan:

$\mathrm{Q}_{\text {DM }}=$ Kebutuhan air domestik ( $\mathrm{m}^{3} /$ tahun)

$\mathrm{q}=$ Konsumsi air (liter/kapita/hari)

$\mathrm{P}=$ Jumlah penduduk 


\section{Kebutuhan Air Non Domestik}

Kebutuhan air non domestik pada penelitian ini adalah akumulasi kebutuhan air non domestik berdasarkan SNI dan kebutuhan air rumah kost kawasan pendidikan tinggi di Kecamatan Jatinangor. Besar kebutuhan air non domestik berdasarkan SNI adalah 30\% dari kebutuhan air domestik (Badan Standardisasi Nasional, 2015). Standar yang kebutuhan air rumah kost di Kawasan pendidikan tinggi di Kecamatan Jatinangor menggunakan hasil penelitian di Kawasan Pendidikan Tembalang untuk rumah kost sederhana yaitu 115,86 liter/orang/hari (Indriastuti \& Widjonarko, 2013).

\section{Kebutuhan Air Pertanian}

Kebutuhan air pertanian dihitung dengan formula berikut:

$$
\mathrm{Q}_{\mathrm{IR}}=\mathrm{L} \times \text { It } \mathrm{x} \text { a }
$$

keterangan:

$$
\begin{aligned}
\mathrm{Q}_{\mathrm{IR}}= & \text { Kebutuhan air irigasi (m³/tahun) } \\
\mathrm{L}= & \text { Luas lahan pertanian (ha) } \\
\mathrm{It}= & \text { Intensitas penanaman (jumlah } \\
& \text { musim/tahun } \mathrm{x} 3600 \mathrm{detik} / \mathrm{jam} \times 24 \\
& \text { jam/hari } \times \text { jumlah hari/musim) }
\end{aligned}
$$

$\mathrm{a}=$ standar penggunaan irigasi (merujuk SE PUPR Nomor 07 Tahun 2018 Tahun 2018 kebutuhan air tanaman padi adalah 1 liter/detik/ha dan kebutuhan air palawija adalah 0,8 liter/detik/ha) (Kementerian Pekerjaan Umum dan Perumahan Rakyat, 2018)

\section{Kebutuhan Air Industri}

Kebutuhan air industri dihitung berdasarkan jumlah dan jenis (besar, sedang, dan kecil) industri. Standar kebutuhan air industri yang digunakan adalah sebagai berikut:

1. Kebutuhan air industri besar adalah $3.805 .200 \mathrm{~m}^{3} /$ tahun.

2. Kebutuhan air industri sedang adalah $1.064 .880 \mathrm{~m}^{3} /$ tahun.

3. Kebutuhan air industri kecil adalah $20.400 \mathrm{~m}^{3} /$ tahun (Resubun, 2017).

\section{Kebutuhan Air Peternakan}

Jumlah kebutuhan air sektor peternakan bergantung pada jumlah serta jenis ternak (Badan Standardisasi Nasional, 2015).
Persamaan untuk mengestimasi kebutuhan air peternakan adalah sebagai berikut:

$\begin{aligned} \mathrm{Q}_{\mathrm{E}}= & \left(\mathrm{q}_{(1)} \times \mathrm{P}_{(1)}+\mathrm{q}_{(2)} \times \mathrm{P}_{(2)}+\mathrm{q}_{(3)} \times \mathrm{P}_{(3)}\right) \\ \text { keterangan: } & \\ \mathrm{Q}_{\mathrm{E}}= & \text { Kebutuhan air untuk ternak (1/hari) } \\ \mathrm{q}_{(1)}= & \begin{array}{l}\text { Kebutuhan air ternak besar } \\ \text { (1/ekor/hari) }\end{array} \\ \mathrm{q}_{(2)}= & \begin{array}{l}\text { Kebutuhan air ternak sedang } \\ \text { (1/ekor/hari) }\end{array} \\ \mathrm{q}_{(3)}= & \begin{array}{l}\text { Kebutuhan air ternak kecil } \\ \text { (1/ekor/hari) }\end{array} \\ \mathrm{P}_{(1)}= & \text { Jumlah ternak besar (ekor) } \\ \mathrm{P}_{(2)}= & \text { Jumlah ternak sedang (ekor) } \\ \mathrm{P}_{(3)}= & \text { Jumlah ternak kecil (ekor) }\end{aligned}$

\section{Kebutuhan Air Perikanan}

Kebutuhan air untuk perikanan dihitung dengan persamaan berikut:

$$
\mathrm{Q}_{\mathrm{fp}}=\frac{\mathrm{q}(\mathrm{fp})}{1.000} \times \mathrm{A}(\mathrm{fp}) \times 10.000
$$

keterangan:

$\mathrm{Q}_{\mathrm{fp}}=$ Kebutuhan air untuk perikanan $\left(\mathrm{m}^{3} /\right.$ hari $)$

$\mathrm{q}_{(\mathrm{fp})}=$ Kebutuhan air untuk perikanan (7 $\mathrm{mm} / \mathrm{hari} / \mathrm{ha}$ )

$\mathrm{A}_{(\mathrm{fp})}=$ Luas kolam ikan (ha) (Badan Standardisasi Nasional, 2015).

\section{Kebutuhan Air Total}

Kebutuhan air total merupakan akumulasi kebutuhan air 6 sektor yaitu kebutuhan air sektor domestik, non domestik, pertanian, industri, peternakan, dan perikanan.

\section{Neraca Air Sub DAS Cikeruh}

Neraca air adalah selisih ketersediaan dan kebutuhan air.

$$
\Delta \mathrm{S}=\mathrm{Q}_{\text {ketersediaan }}-\mathrm{Q}_{\text {kebutuhan }}
$$

Keterangan:

$\mathrm{Q}_{\text {ketersediaan }}=$ Total ketersediaan air ( $\mathrm{m}^{3} /$ tahun)

$\mathrm{Q}_{\text {kebutuhan }}=$ Total kebutuhan air $\left(\mathrm{m}^{3} /\right.$ tahun $)$

\section{HASIL DAN PEMBAHASAN}

\section{Ketersediaan Air Sub DAS Cikeruh Berdasarkan Metode Mock}

Perhitungan data iklim rata-rata merupakan langkah awal dalam perhitungan ketersediaan air berdasarkan metode mock. Curah hujan rata-rata Sub DAS Cikeruh dihitung berdasarkan metode poligon thiessen, rata-rata tertinggi terjadi pada bulan Maret yaitu 320 $\mathrm{mm} /$ bulan dan terendah terjadi pada bulan 
Agustus yaitu $18 \mathrm{~mm} /$ bulan. Temperatur ratarata tertinggi dan terendah secara berurutan di Sub DAS Cikeruh terjadi pada bulan September - Oktober yaitu $30^{\circ} \mathrm{C}$ dan Agustus yaitu $12,9^{\circ} \mathrm{C}$. Kelembaban relatif rata-rata tertinggi dan terendah secara berurutan di Sub DAS Cikeruh terjadi pada bulan Mei yaitu 97\% dan bulan Oktober yaitu $60 \%$. Kecepatan angin rata-rata tertinggi terjadi pada bulan September yaitu 2,1 $\mathrm{m} / \mathrm{s}$ dan terendah terjadi pada bulan Februari hingga April yaitu $1,5 \mathrm{~m} / \mathrm{s}$. Persentase penyinaran matahari tertinggi terjadi pada bulan Agustus dan September yaitu 100\% dan terendah terjadi pada bulan Februari yatu $47,52 \%$.

Perhitungan dan penentuan parameter DAS merupakan langkah lanjutan agar perhitungan ketersediaan air menggunakan metode mock dapat dilakukan. Berikut adalah nilai parameter Sub DAS Cikeruh yang digunakan untuk menghitung ketersediaan air berdasarkan metode mock:

Tabel 2. Hasil Perhitungan Komponen Ketersediaan Air Berdasarkan Metode Mock

\begin{tabular}{clccccccc}
\hline No & Bulan & Ep & Ea & WS & BF & DRO & SRO & TRO \\
\hline 1 & Januari & 118,51 & 113,71 & 68,71 & 21,34 & 42,96 & 16,52 & 80,82 \\
2 & Februari & 105,53 & 103,73 & 164,04 & 24,86 & 102,56 & 13,38 & 140,81 \\
3 & Maret & 115,10 & 117,15 & 204,76 & 29,60 & 128,02 & 6,27 & 163,89 \\
4 & April & 119,22 & 116,86 & 116,83 & 33,79 & 73,05 & 0,00 & 106,84 \\
5 & Mei & 116,87 & 100,62 & 31,66 & 20,41 & 19,79 & 21,96 & 62,16 \\
6 & Juni & 109,32 & 86,08 & 11,23 & 24,51 & 7,02 & 35,04 & 66,57 \\
7 & Juli & 118,58 & 89,61 & 2,09 & 35,72 & 1,31 & 22,91 & 59,94 \\
8 & Agustus & 133,89 & 98,59 & 0,00 & 16,49 & 0,00 & 11,31 & 27,80 \\
9 & September & 145,50 & 109,14 & 9,52 & 33,97 & 5,95 & 7,79 & 47,71 \\
10 & Oktober & 143,72 & 117,81 & 57,03 & 29,19 & 35,66 & 21,16 & 86,00 \\
11 & November & 127,05 & 118,17 & 136,78 & 25,93 & 85,52 & 7,78 & 119,23 \\
12 & Desember & 119,20 & 116,72 & 142,74 & 29,71 & 89,24 & 0,00 & 118,95 \\
\hline
\end{tabular}

Keterangan: Ep = Evapotranspirasi potensial ( $\mathrm{mm} / \mathrm{bulan}), \mathrm{Ea}=$ Evapotranspirasi aktual (mm/bulan), WS = Water Surplus (mm/bulan), BF = Base Flow (mm/bulan), DRO = Direct Runoff (mm/bulan), SRO = Storm Runoff $(\mathrm{mm} / \mathrm{bulan})$, TRO = Total Runoff (mm/bulan)

Debit berdasarkan metode mock adalah hasil perkalian antara TRO dengan luas daerah tangkapan atau catchment area. Luas Sub DAS Cikeruh adalah $191.43 \mathrm{~km}^{2}$. Berikut adalah data ketersediaan air Sub DAS Cikeruh yang dihitung berdasarkan metode mock:
Tabel 1. Nilai Parameter FJ Mock Sub DAS

Cikeruh

Parameter F.J. Simbol Satuan Value
Sock

1. Percentage Factor PF $\% 63$

2. Koefisien Infiltrasi

3. Soil Moisture Capacity

4. Exposed Surface m $\% \quad 31,68$

5. Initial

$\begin{array}{lccc}\begin{array}{l}\text { Groundwater } \\ \text { Storage }\end{array} & \text { IGS } & \mathrm{mm} & 140 \\ \begin{array}{l}\text { Konstanta resesi } \\ \text { aliran }\end{array} & \mathrm{k} & - & 0,62- \\ \end{array}$

Data iklim dan data parameter Sub DAS Cikeruh digunakan untuk perhitungan ketersediaan air di Sub DAS Cikeruh. Berikut adalah hasil perhitungan ketersediaan air Sub DAS Cikeruh berdasarkan metode mock: 


\begin{tabular}{clcc}
\hline No & Bulan & $\begin{array}{c}\text { Debit } \\
\text { Mock } \\
\left(\mathbf{m}^{3} / \mathbf{s}\right)\end{array}$ & $\begin{array}{c}\text { Ketersediaan Air } \\
\left(\mathbf{m}^{3} / \text { /bulan }\right)\end{array}$ \\
\hline 4 & April & 7,91 & $20.504 .628,72$ \\
5 & Mei & 4,45 & $11.922 .564,59$ \\
6 & Juni & 4,92 & $12.740 .237,69$ \\
7 & Juli & 4,27 & $11.429 .593,79$ \\
8 & Agustus & 1,99 & $5.319 .577,83$ \\
9 & September & 3,51 & $9.088 .054,50$ \\
10 & Oktober & 6,14 & $16.443 .574,76$ \\
11 & November & 8,80 & $22.822 .268,74$ \\
12 & Desember & 8,49 & $22.747 .564,91$ \\
\hline \multicolumn{2}{c}{ Rata-Rata } & $\mathbf{6 , 5 8}$ & $\mathbf{1 7 . 2 9 3 . 5 2 9 , 0 0}$ \\
\hline \multicolumn{2}{c}{ Total } & $\mathbf{7 9 , 0 0}$ & $\mathbf{2 0 7 . 5 2 2 . 3 4 7 , 9 9}$ \\
\hline
\end{tabular}

\section{Kebutuhan Air Sub DAS Cikeruh}

\section{Kebutuhan Air Domestik}

Kebutuhan air domestik yang dihitung hanya memperhatikan jumlah penduduk tanpa memperhatikan faktor lain yang mempengaruhi seperti kebiasaan dan kondisi ekonomi. Jumlah penduduk Sub DAS Cikeruh berdasarkan adalah 848.401 jiwa sehingga standar kebutuhan air yang digunakan menurut SNI 6728.1-2015 adalah 150 liter/orang/hari. Berikut adalah hasil perhitungan kebutuhan domestik air sub-DAS Cikeruh:

Tabel 4. Kebutuhan Air Domestik Sub DAS Cikeruh

\begin{tabular}{|c|c|c|}
\hline No & Bulan & $\begin{array}{c}\text { Kebutuhan Air } \\
\text { Domestik } \\
\left(\mathrm{m}^{3} / \text { bulan }\right)\end{array}$ \\
\hline 1 & Januari & $3.945 .064,65$ \\
\hline 2 & Februari & $3.690 .544,35$ \\
\hline 3 & Maret & $3.945 .064,65$ \\
\hline 4 & April & $3.817 .804,50$ \\
\hline 5 & Mei & $3.945 .064,65$ \\
\hline 6 & Juni & $3.817 .804,50$ \\
\hline 7 & Juli & $3.945 .064,65$ \\
\hline 8 & Agustus & $3.945 .064,65$ \\
\hline 9 & September & $3.817 .804,50$ \\
\hline 10 & Oktober & $3.945 .064,65$ \\
\hline 11 & November & $3.817 .804,50$ \\
\hline 12 & Desember & $3.945 .064,65$ \\
\hline \multicolumn{2}{|c|}{ Total (m³/tahun) } & 46.577.214,90 \\
\hline \multicolumn{2}{|c|}{ Rata-Rata (m³/bulan) } & 3.881.434,58 \\
\hline
\end{tabular}

\section{Kebutuhan Air Non Domestik}

Kebutuhan total air non domestik adalah akumulasi kebutuhan air non domestik berdasarkan SNI dan kebutuhan air rumah kost. Jumlah mahasiswa yang tercatat berdomisili di Kecamatan Jatinangor pada tahun 2020 adalah 7.173 jiwa. Berikut adalah kebutuhan total air non domestik Sub DAS Cikeruh:

Tabel 5. Kebutuhan Total Air Non Domestik

\begin{tabular}{|c|c|c|}
\hline No & Bulan & $\begin{array}{c}\text { Kebutuhan Total Air } \\
\text { Non Domestik } \\
\left(\mathbf{m}^{\mathbf{3}} / \text { bulan }\right)\end{array}$ \\
\hline 1 & Januari & $1.209 .282,37$ \\
\hline 2 & Februari & $1.131 .264,15$ \\
\hline 3 & Maret & $1.209 .282,37$ \\
\hline 4 & April & $1.170 .273,26$ \\
\hline 5 & Mei & $1.209 .282,37$ \\
\hline 6 & Juni & $1.170 .273,26$ \\
\hline 7 & Juli & $1.209 .282,37$ \\
\hline 8 & Agustus & $1.209 .282,37$ \\
\hline 9 & September & $1.170 .273,26$ \\
\hline 10 & Oktober & $1.209 .282,37$ \\
\hline 11 & November & $1.170 .273,26$ \\
\hline 12 & Desember & $1.209 .282,37$ \\
\hline \multicolumn{2}{|c|}{ Total (m³/tahun) } & 14.277.333,81 \\
\hline \multicolumn{2}{|c|}{ Rata-Rata (m³/bulan) } & 1.189.777,82 \\
\hline
\end{tabular}

\section{Kebutuhan Air Pertanian}

Kebutuhan air pertanian pada penelitian ini merupakan akumulasi dari kebutuhan air tanaman padi dan palawija. Luas sawah di Sub DAS Cikeruh adalah 46,51 $\mathrm{km}^{2}$. Berikut adalah kebutuhan air pertanian Sub DAS Cikeruh:

Tabel 6. Kebutuhan Air Pertanian Sub DAS Cikeruh

\begin{tabular}{clc}
\hline No & \multicolumn{1}{c}{ Bulan } & $\begin{array}{c}\text { Kebutuhan Air } \\
\text { Pertanian }\left(\mathbf{m}^{\mathbf{3}} \text { /bulan }\right)\end{array}$ \\
\hline 1 & Januari & $12.054 .621,31$ \\
2 & Februari & $1.886 .716,80$ \\
3 & Maret & $12.457 .988,35$ \\
4 & April & $12.056 .117,76$ \\
5 & Mei & $12.457 .988,35$ \\
6 & Juni & $10.104 .341,76$ \\
7 & Juli & - \\
8 & Agustus & - \\
9 & September & -
\end{tabular}




\begin{tabular}{clc}
\hline No & \multicolumn{1}{c}{ Bulan } & $\begin{array}{c}\text { Kebutuhan Air } \\
\text { Pertanian }\left(\mathbf{m}^{\mathbf{3}} / \mathrm{bulan}\right)\end{array}$ \\
\hline 10 & Oktober & $12.054 .621,31$ \\
11 & November & $11.665 .762,56$ \\
12 & Desember & $12.054 .621,31$ \\
\hline \multicolumn{2}{c}{ Total $\left(\mathbf{m}^{\mathbf{3}} /\right.$ tahun$)$} & $\mathbf{9 6 . 7 9 2 . 7 7 9 , 5 2}$ \\
\hline Rata-Rata $\left(\mathbf{m}^{\mathbf{3}} / \mathbf{b u l a n}\right)$ & $\mathbf{8 . 0 6 6 . 0 6 4 , 9 6}$ \\
\hline
\end{tabular}

\section{Kebutuhan Air Industri}

Berdasarkan data yang diperoleh dari kantor kecamatan yang berada di Wilayah Sub DAS Cikeruh dan dari BPS, terdapat 50 industri besar, 106 industri sedang, dan 16 industri kecil di Sub DAS Cikeruh. Berikut adalah kebutuhan air industri di Sub DAS Cikeruh:

Tabel 7. Kebutuhan Air Industri Sub DAS Cikeruh

\begin{tabular}{|c|c|c|}
\hline No & Bulan & $\begin{array}{c}\text { Kebutuhan Air } \\
\text { Industri (m³/bulan) }\end{array}$ \\
\hline 1 & Januari & $25.758 .034,19$ \\
\hline 2 & Februari & $24.096 .225,53$ \\
\hline 3 & Maret & $25.758 .034,19$ \\
\hline 4 & April & $24.927 .129,86$ \\
\hline 5 & Mei & $25.758 .034,19$ \\
\hline 6 & Juni & $24.927 .129,86$ \\
\hline 7 & Juli & $25.758 .034,19$ \\
\hline 8 & Agustus & $25.758 .034,19$ \\
\hline 9 & September & $24.927 .129,86$ \\
\hline 10 & Oktober & $25.758 .034,19$ \\
\hline 11 & November & $24.927 .129,86$ \\
\hline 12 & Desember & $25.758 .034,19$ \\
\hline \multicolumn{2}{|c|}{ Total (m³/tahun) } & 304.110.984,33 \\
\hline \multicolumn{2}{|c|}{ Rata-Rata (m³/bulan) } & 25.342.582,03 \\
\hline
\end{tabular}

\section{Kebutuhan Air Peternakan}

Jumlah ternak yang terdapat di Sub DAS Cikeruh menurut data BPS adalah 2.832 ekor sapi, 364 ekor kerbau, 96 ekor kuda, 1.420 ekor kambing, 24.708 ekor domba, dan 285.264 ekor unggas. Standar kebutuhan air ternak yang digunakan merujuk pada SNI 6728.1-2015. Berikut adalah kebutuhan air peternakan di Sub DAS Cikeruh:

Tabel 8. Kebutuhan Air Peternakan Sub DAS Cikeruh

\begin{tabular}{ccc}
\hline No. & Bulan & $\begin{array}{c}\text { Kebutuhan Air } \\
\text { Peternakan }\left(\mathbf{m}^{\mathbf{3}} / \mathbf{b u l a n}\right)\end{array}$ \\
\hline 1 & Januari & $13.437,83$
\end{tabular}

\begin{tabular}{clc}
\hline No. & \multicolumn{1}{c}{ Bulan } & $\begin{array}{c}\text { Kebutuhan Air } \\
\text { Peternakan }\left(\mathbf{m}^{\mathbf{3}} / \mathbf{b u l a n}\right)\end{array}$ \\
\hline 2 & Februari & $12.570,87$ \\
3 & Maret & $13.437,83$ \\
4 & April & $13.004,35$ \\
5 & Mei & $13.437,83$ \\
6 & Juni & $13.004,35$ \\
7 & Juli & $13.437,83$ \\
8 & Agustus & $13.437,83$ \\
9 & September & $13.004,35$ \\
10 & Oktober & $13.437,83$ \\
11 & November & $13.004,35$ \\
12 & Desember & $13.437,83$ \\
\hline \multicolumn{2}{c}{ Total $\left(\mathbf{m}^{\mathbf{3} / \text { tahun })}\right.$} & $\mathbf{1 5 8 . 6 5 3 , 0 9}$ \\
\hline Rata-Rata $\left(\mathbf{m}^{\mathbf{3}} / \mathbf{b u l a n}\right)$ & $\mathbf{1 3 . 2 2 1 , 0 9}$ \\
\hline
\end{tabular}

\section{Kebutuhan Air Perikanan}

Berdasarkan hasil analisis menggunakan software Arcgis, luas kolam/danau/waduk di Sub DAS Cikeruh adalah $0,15 \mathrm{~km}^{2}$. Berikut adalah hasil perhitungan kebutuhan air sektor perikanan Sub DAS Cikeruh: Tabel 9. Kebutuhan Air Perikanan Sub DAS Cikeruh

\begin{tabular}{clc}
\hline No & \multicolumn{1}{c}{ Bulan } & $\begin{array}{c}\text { Kebutuhan Air } \\
\text { Perikanan }\left(\mathbf{m}^{\mathbf{3}} / \mathbf{b u l a n}\right)\end{array}$ \\
\hline 1 & Januari & $33.012,70$ \\
2 & Februari & $30.882,85$ \\
3 & Maret & $33.012,70$ \\
4 & April & $31.947,78$ \\
5 & Mei & $33.012,70$ \\
6 & Juni & $31.947,78$ \\
7 & Juli & $33.012,70$ \\
8 & Agustus & $33.012,70$ \\
9 & September & $31.947,78$ \\
10 & Oktober & $33.012,70$ \\
11 & November & $31.947,78$ \\
12 & Desember & $33.012,70$ \\
\hline Total (m $/$ tahun) & $\mathbf{3 8 9 . 7 6 2 , 8 8}$ \\
\hline Rata-Rata (m /bulan) & $\mathbf{3 2 . 4 8 0 , 2 4}$ \\
\hline
\end{tabular}

7. Kebutuhan Air Total Sub DAS Cikeruh Kebutuhan air total merupakan akumulasi kebutuhan air 6 sektor yaitu sebagai berikut: Tabel 10. Kebutuhan Air Total Sub DAS Cikeruh

\begin{tabular}{clc}
\hline No & Bulan & $\begin{array}{c}\text { Kebutuhan Air Total } \\
\left(\mathbf{m}^{\mathbf{3}} / \mathbf{b u l a n}\right)\end{array}$ \\
\hline 1 & Januari & $43.013 .453,06$ \\
2 & Februari & $30.848 .204,56$ \\
3 & Maret & $43.416 .820,10$ \\
4 & April & $42.016 .277,52$
\end{tabular}




\begin{tabular}{clc}
\hline No & Bulan & $\begin{array}{c}\text { Kebutuhan Air Total } \\
\left(\mathbf{m}^{\mathbf{3}} / \mathbf{b u l a n}\right)\end{array}$ \\
\hline 5 & Mei & $43.416 .820,10$ \\
6 & Juni & $40.064 .501,52$ \\
7 & Juli & $30.958 .831,75$ \\
8 & Agustus & $30.958 .831,75$ \\
9 & September & $29.960 .159,76$ \\
10 & Oktober & $43.013 .453,06$ \\
11 & November & $41.625 .922,32$ \\
12 & Desember & $43.013 .453,06$ \\
\hline \multicolumn{2}{c}{ Total $\left(\mathbf{m}^{3} /\right.$ tahun $)$} & $462.306 .728,53$ \\
\hline Rata-Rata $\left(\mathbf{m}^{3} / \mathbf{b u l a n}\right)$ & $38.525 .560,71$ \\
\hline
\end{tabular}

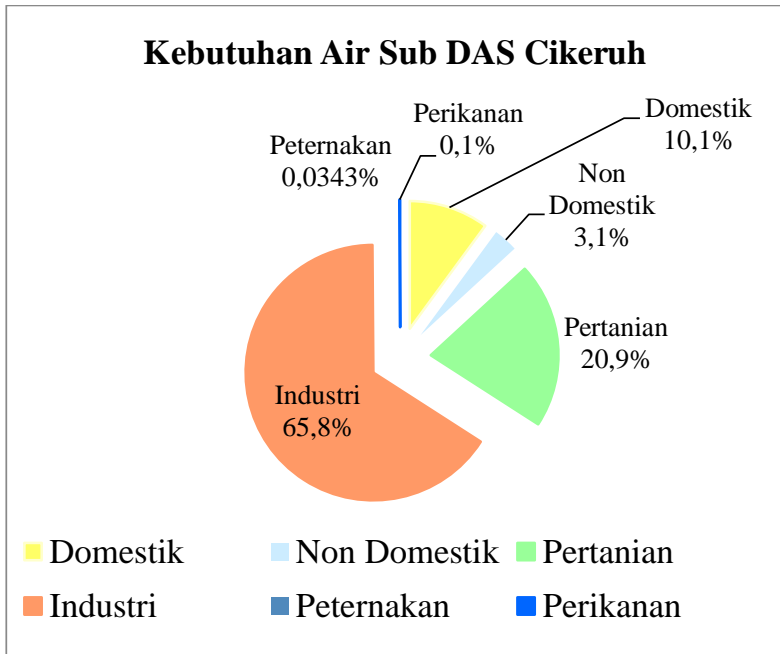

Gambar 1. Kebutuhan Air Sub DAS Cikeruh

\section{Neraca Air Sub DAS Cikeruh}

Neraca air adalah selisih antara ketersediaan dan kebutuhan air. Selisih ketersediaan dan kebutuhan air yang bernilai positif atau surplus menunjukan ketersediaan air mampu mencukupi semua kebutuhan air di wilayah tersebut. Selisih bernilai negatif atau defisit menunjukan bahwa kebutuhan air di wilayah tersebut belum seluruhnya terpenuhi. Neraca air dapat memberikan gambaran mengenai tingkat pemenuhan kebutuhan air pada suatu wilayah. Berikut adalah hasil perhitungan neraca air Sub DAS Cikeruh tahun 2020:

Tabel 11. Neraca Air Sub DAS Cikeruh

\begin{tabular}{lcccc}
\hline \multicolumn{1}{c}{ Bulan } & Ketersediaan Air & Kebutuhan Air & Neraca Air & Keterangan \\
\hline Januari & $15.493 .581,12$ & $43.013 .453,06$ & $-27.519 .871,94$ & Defisit \\
Februari & $27.638 .120,20$ & $30.848 .204,56$ & $-3.210 .084,37$ & Defisit \\
Maret & $31.372 .581,14$ & $43.416 .820,10$ & $-12.044 .238,96$ & Defisit \\
April & $20.504 .628,72$ & $42.016 .277,52$ & $-21.511 .648,79$ & Defisit \\
Mei & $11.922 .564,59$ & $43.416 .820,10$ & $-31.494 .255,51$ & Defisit \\
Juni & $12.740 .237,69$ & $40.064 .501,52$ & $-27.324 .263,82$ & Defisit \\
Juli & $11.429 .593,79$ & $30.958 .831,75$ & $-19.529 .237,96$ & Defisit \\
Agustus & $5.319 .577,83$ & $30.958 .831,75$ & $-25.639 .253,91$ & Defisit \\
September & $9.088 .054,50$ & $29.960 .159,76$ & $-20.872 .105,26$ & Defisit \\
Oktober & $16.443 .574,76$ & $43.013 .453,06$ & $-26.569 .878,30$ & Defisit \\
November & $22.822 .268,74$ & $41.625 .922,32$ & $-18.803 .653,57$ & Defisit \\
Desember & $22.747 .564,91$ & $43.013 .453,06$ & $-20.265 .888,15$ & Defisit \\
\hline
\end{tabular}

\section{Upaya Rekomendasi Konservasi Air yang} Dapat dilakukan di Sub DAS Cikeruh

Berdasarkan hasil analisis ketersediaan dan kebutuhan air di Sub DAS Cikeruh dan analisis neraca air, dapat diketahui bahwa terjadi defisit air di Sub DAS Cikeruh. Upaya konservasi air menjadi penting untuk mengatasi defisit air yang terjadi sepanjang tahun di Sub DAS Cikeruh. 
Salah satu upaya konservasi air yang dapat dilakukan di Sub DAS Cikeruh adalah melalui pengelolaan sumber daya air terpadu (Integrated Water Resources Management (IWRM)). Pengelolaan sumber daya air terpadu (Integrated Water Resources Management (IWRM)) adalah suatu proses yang mengkoordinasikan pengelolaan sumberdaya air dan sumberdaya lahan dalam suatu wilayah sungai, agar tetap memperoleh manfaat ekonomi dan kesejahteraan yang maksimal tanpa menyebabkan kerusakan ekosistem (tetap memperhatikan keberlanjutan)(Sutikno, 2014).

Masalah ketersediaan air erat kaitannya dengan daerah hulu yang berperan sebagai daerah resapan air. Perkembangan yang terjadi saat ini mendorong semua masyarakat termasuk masyarakat yang bermukim di wilayah hulu DAS untuk meningkatkan perekonomian dalam rangka memperbaiki taraf hidup dan seringkali untuk melakukan hal tersebut masyarakat tidak memperhatikan lingkungan. Upaya pengelolaan sumber daya air terpadu yang dapat dilakukan di Sub DAS Cikeruh untuk mengatasi kelangkaan air adalah pelestarian daerah hulu, perencanaan penggunaan lahan, dan penerapan luas minimal hutan untuk menjaga daerah resapan air (Resubun, 2017). Upaya tersebut harus tetap memperhatikan mata pencaharian dan meningkatkan perekonomian masyarakat di wilayah tersebut secara berkesinambungan (Sutikno, 2014).

Upaya lain yang dapat dilakukan dalam rangka pengelolaan sumber daya air terpadu adalah membangun sumur resapan (Resubun, 2017). Sumur resapan dapat menjadi solusi yang mampu mengatasi air yang berlimpah saat musim hujan. Sumur resapan dapat membantu meningkatkan infiltrasi. Sumur resapan dapat mengurangi air yang menjadi limpasan.

\section{KESIMPULAN}

1. Ketersediaan air di Sub DAS berdasarkan metode mock adalah 207.552.347,99 $\mathrm{m}^{3} /$ tahun dimana ketersediaan air tertinggi terjadi pada bulan Maret yaitu 31.372.581,14 $\mathrm{m}^{3} /$ bulan dan ketersediaan air terendah terjadi pada bulan Agustus yaitu $5.319 .577,83 \mathrm{~m}^{3} /$ bulan.

2. Kebutuhan air total Sub DAS Cikeruh adalah 462.306.728,53 $\mathrm{m}^{3} /$ tahun dengan uraian kebutuhan air domestik 46.577.214,90 $\mathrm{m}^{3} /$ tahun, kebutuhan air non domestik $\quad 14.277 .333,81 \quad \mathrm{~m}^{3} /$ tahun, kebutuhan air pertanian 96.792.779,52 $\mathrm{m}^{3} /$ tahun, kebutuhan air industri 304.342.984,33 $\mathrm{m}^{3} /$ tahun, kebutuhan air peternakan 158.653,09 $\mathrm{m}^{3} /$ tahun, dan kebutuhan air perikanan 389.762,88 $\mathrm{m}^{3} /$ tahun.

3. Sektor dengan kebutuhan air tertinggi adalah industri yaitu mencapai $65,8 \%$ dari kebutuhan air total dan sektor dengan kebutuhan air terendah adalah peternakan yaitu $0,0343 \%$ dari kebutuhan air total.

4. Kondisi neraca air Sub DAS Cikeruh adalah defisit sepanjang tahun.

5. Ketersediaan air di sub-DAS Cikeruh hanya mampu memenuhi kebutuhan air sektor domestik, non domestik, peternakan, dan perikanan.

\section{DAFTAR PUSTAKA}

Amaru, K., Perwitasari, S. D. N., Bafdal, N., \& Abidin, J. (2013). Penentuan Tingkat Bahaya Erosi dengan Menggunakan Sistem Informasi Geografis di Sub DAS Cikeruh Kabupaten Bandung-Sumedang. Teknotan, 7, 1019-1025.

Badan Pusat Statistik Provinsi Jawa Barat. (2020). Provinsi Jawa Barat Dalam Angka 2020. BPS Provinsi Jawa Barat.

Badan Standardisasi Nasional. (2015). SNI 6728.1:2015 Penyusunan neraca spasial sumber daya alam - Bagian 1: Sumber daya air. BSN.

Haryanto, E. T., Herwanto, T., \& Kendarto, D. R. (2007). Perubahan Bentuk Penggunaan Lahan dan Implikasinya Terhadap Koefisien Air Larian DAS Citarum Hulu Jawa-Barat [Land-use Change and the Implication to Runoff Coefficient in the Upper Citarum Catchment West Java]. Jurnal Bionatura, 9(1), 1-15.

Indriastuti, W., \& Widjonarko, W. (2013). Pola Konsumsi Air Bersih Pada Rumah Kost Di Kawasan Pendidikan Tinggi Tembalang. Teknik Perencanaan Wilayah Kota, 2(3), 609-618.

Kementerian Pekerjaan Umum dan Perumahan 
Rakyat. (2018). Surat Edaran Menteri Pekerjaan Umum dan Perumahan Rakyat Nomor 7 Tahun 2018 Tentang Pedoman Pembangunan Embung Kecil dan Bangunan Penampung Air Lainnya di Desa.

Resubun, M. L. (2017). Analisis Ketersediaan dan Kebutuhan Air di Daerah Aliran Sungai Cisangkuy. Institut Pertanian Bogor.

Sutikno, S. (2014). Pengelolaan Sumber Daya Air Terpadu (Integrated Water Resources Management, IWRM). Jurnal Mesa Fakultas Teknik Universitas Subang, 9-15.

Zarkasih, Rohmat, \& Nur. (2018). Evaluasi Ketersediaan dan Tingkat Pemenuhan Kebutuhan Air di SUB DAS Cikeruh. Jurnal Pendidikan Geografi, 18(1), 72-80. 